\title{
Effects of Different Home Storage Conditions and Preservation on Some Chemical Constituents of Tomato (Lycopersicon Esculentum)
}

\author{
Ibironke A. Ajayi and Rotimi A. Oderinde \\ Industrial Chemistry unit, Chemistry Department, Faculty of Science, University of Ibadan, Ibadan, Nigeria
}

\begin{abstract}
This study was conducted to investigate the effects of different home storage conditions and preservation on some chemical constituents of tomato (Lycopersicon esculentum). The experiment involved three post-harvest treatments comprising of fruits without preservative used as the control, fruits preserved with groundnut oil and fruits preserved with salt. All these were further divided into sub samples and subjected to different home storage conditions for the period of 8 weeks. The tomato samples were evaluated for changes in total solid, insoluble solid, pH, sugar, salt content, ascorbic acid and ash contents. Results obtained indicated that total soluble solid, insoluble solid, $p H$, sugar, salt, ascorbic acid and ash contents of fresh and dehydrated samples decreased with different storage conditions while their acidity showed an increase. Powdered tomato samples were found to withstand long term storage and their chemical constituents showed minimal change over the period of the study. The results revealed that preservation by powdering technique proved to be a better technique and worthy of further industrial investigation.
\end{abstract}

Key words: Chemical constituents, Lycopersicon esculentum, home storage, preservation,

\section{Introduction}

Tomato (Lycopersicon esculentum) is one of the most widely consumed fresh vegetable in the world (Thybo et al., 2006). They are fruits, but they are commonly referred to as vegetable. The edible part of the fruit is known as the power house of nutrition (Tyssandier et al., 2004; Weisburger, 2002). Fresh-market tomatoes are a popular and versatile fruit vegetable, making significant contributions to human nutrition throughout the world for their content of sugars, acids, vitamins, minerals, lycopene and other carotenoids, among other constituents (Simonne et al., 2006). Being a climacteric and perishable vegetable, tomatoes have a very short life span, usually 2-3 weeks. Tomatoes are consumed widely throughout the world and their consumption has recently been demonstrated to possess health benefits because of their rich content of phytonutrients (Hsu et al., 2008) with an average tomato supplying about $40 \%$ of the adult United States Recommended Daily Allowances (RDA) of $60 \mathrm{mg}$ (Charanjeet et al., 2004).

There is a rapid development of tomato processing industries in recent decades with a series of interlinked activities such as production of salad, soup, juice, puree, paste and powder and extraction of oil from the pulp and the demand for dehydrated tomato is increasing rapidly both in domestic and in international market with major portion of it being used for preparation of convenience food since it has limited shelf life and highly perishable at ambient conditions (Purseglove et al., 2001). Postharvest recommendations indicate that tomatoes should be stored at $10^{\circ} \mathrm{C}$ or higher to avoid chilling injury (Roberts et al., 2008) and even $10^{\circ} \mathrm{C}$ may be detrimental to tomato flavour quality (Maul et al., 2000). Tomatoes are sometimes held at lower than recommended temperatures. It is routinely used as components on fresh cut vegetable trays under modified atmospheres, with expected shelf-life of $14-18$ days at $5-10^{\circ} \mathrm{C}$. A few studies have characterized changes in small tomatoes stored at below recommended temperatures alone or in combination with modified atmosphere packaging (Akbudak et al., 2007). Different studies explained that calcium chloride reduced post-harvest decay, controlled development of physiological disorders, improved quality and delayed aging or ripening (Stanly et al., 1995). It improves the skin strength making the cell wall and tissues more resistant and less accessible to the enzymes that are produced by fungi and bacteria, limiting infection while controlling ripening, softening, storage breakdown, rotting and decay at the same time (Hong et al., 1999)

An increase in the storage life and improvement of tomato fruit quality is really desirable and the initial step required for ensuring successful marketing is to harvest the crop at the optimum stage of maturity. Full red, vine-ripened tomatoes may be ideal to meet the needs of a roadside stand, but totally wrong if the fruits are destined for long distance shipment (Opiyo et al., 2005). Extending the shelf life of tomatoes is very important for domestic and export markets. Storage at $13^{\circ} \mathrm{C}$ was more favourable as compared to $24^{\circ} \mathrm{C}$ for prolonged shelf life and increasing vitamin C content of fruits (Mustafa et al., 1994). Tomatoes are sold at a premium in many of the large retail stores in the country. Preservation of vegetable product is difficult in the tropics because of poor transportation networks and high environmental temperatures that favours decay rather than 
storage. There is an interest in finding ways to improve the shelf life. Safe and low cost methodologies that can extend the shelf life while at the same time retain the quality under ambient as well as cold conditions need to be evaluated. Present study therefore evaluates the effect of home storage and preservation on the chemical constituents of tomato.

\subsection{Materials}

\section{Materials and Methods}

Tomato fruits (harvested at mature-green stage), a local variety cultivated in the Northern part of Nigeria, were obtained from a local market in Ibadan, Oyo State. Tomatoes were selected for their absence of defects, firmness, uniformity of size and red colour. After the collection, they were stored at room temperature.

\subsection{Sample preparation}

Four medium baskets of tomatoes weighing almost $8 \mathrm{~kg}$ were blended using a blender. It was then divided into two in the ratio of 1:3. The first ratio was regarded as fresh $(\mathrm{F})$ throughout the work while the second ratio was dehydrated to a paste-like form and labeled as dehydrated (D). The powdering technique used for preparing the powder samples involved slicing of another $10 \mathrm{~kg}$ of tomatoes and drying them in an oven at about $75^{\circ} \mathrm{C}$ on a flat glass ware for about $20 \mathrm{hrs}$. The dried tomatoes were then blended in a blender thereby turning them into powder $(\mathrm{P})$ form.

\subsection{Sample Preservation and Storage}

Each of the three batches of the tomato samples was divided into six (1-litre) sample bottles. No preservative was added to the samples in the first two bottles. One of the said bottles was then stored in the fridge and the other was stored in the laboratory at room temperature. The samples in the next two bottles were preserved with groundnut oil while the samples in the last two bottles were preserved with salt. They were then respectively stored away in like manner as for the first two bottles.

\subsection{Sample Documentation}

Samples were labeled after preparation with a 3-lettered code. The first digit letter can either be F (fresh), D (Dehydrated) or P (powdered), the middle can either be a (ordinary without preservative), $\mathrm{g}$ (groundnut oil as preservative) or $\mathrm{s}$ (salt as preservative) while the last letter can either be $\mathrm{O}$ (outside storage) or F (fridge storage). For example, FoO would be fresh, ordinary, outside meaning a fresh sample with no preservative and stored outside. DsF will be dehydrated, salted, fridge etc. which means a dehydrated sample, preserved with salt and stored in a fridge. An inventory of samples used in this work was given below. Altogether 16 samples were analyzed. The documentation of the samples is shown on table 1 below.

\section{Table 1. Sample documentation}

\begin{tabular}{|ll|ll|ll|}
\hline \multicolumn{2}{|l|}{ FRESH FORM } & \multicolumn{2}{|l|}{ DEHYDRATED FORM } & \multicolumn{2}{l|}{ POWDER FORM } \\
\hline FoO & FoF & DoO & DoF & PoO & PoF \\
\hline FgO & FgF & DgO & DgF & \multicolumn{2}{|l|}{-} \\
\hline FsO & FsF & DsO & DsF & PsO & PsF \\
\hline
\end{tabular}

\subsection{Chemical Analyses}

\subsubsection{Total soluble solids}

This was determined by the tentative method for total solids in tomato products, Methods of Analysis AOAC (1984). 1g of the tomato sample was accurately weighed into a dry weight dish. The tomato was spread evenly over the bottom surface of the dish with a fine jet of water and dried in an oven at $70^{\circ} \mathrm{C}$ until constant weight was obtained.

\subsubsection{Insoluble solids}

$3 \mathrm{~g}$ of the tomato sample was accurately weighed into a beaker and $100 \mathrm{ml}$ of distilled water was added to it. It was then boiled for 30mins with occasional stirring. The sample was filtered and the residue washed with $50 \mathrm{ml}$ of $\mathrm{H}_{2} \mathrm{O}$ after which it was scrapped back into the beaker and further boiled in $50 \mathrm{ml} \mathrm{of} \mathrm{H}_{2} \mathrm{O}$ for another 15mins. The sample was then filtered again, this time using a weighed filtered paper and dried in an oven at $100^{\circ} \mathrm{C}$ until constant weight was obtained. 


\subsection{3 $\mathrm{pH}$ and Acidity}

The $\mathrm{pH}$ of the tomato samples was determined by a pH meter following the method of AOAC (1984).

\subsubsection{Salt content}

In determining the salt content of the tomato samples, direct titration (Mohr) method was used in which case, potassium chromate (5\% solution) which is Mohr indicator was used as the indicator (Pearson, 1976). $10 \mathrm{ml}$ of $3 \% \mathrm{H}_{2} \mathrm{O}$ solution of the tomato sample was titrated with $0.1 \mathrm{M} \mathrm{AgNO}_{3}$ using $1 \mathrm{ml}$ of Mohr indicator with the end point being reddish-brownish colour production. The salt content was then calculated and reported as sodium chloride.

\subsubsection{Sugar content}

The sugar content of the tomato sample was determined using Lane and Eynon's method as reported by Mozunder et al. (2012). An amount of $25 \mathrm{ml}$ of standard invert solution was pipette into a $100 \mathrm{ml}$ volumetric flask and about $50 \mathrm{ml}$ of water was added. A few drops of phenolphthalein indicator was added and neutralized with $20 \% \mathrm{NaOH}$ until the solution turned pink.

\subsubsection{Ascorbic acid}

Ascorbic acid of the tomato samples was determined using the method of Pearson (1976).

\subsubsection{Potassium content}

The determination of potassium was done following the method outlined in Pearson (1982). A series of solution was prepared from the freshly prepared diluted potassium stock solution containing 10, 12, 14, 16, 18 and $20 \mathrm{mg} / \mathrm{l} \mathrm{K}_{2} \mathrm{O}$. The potassium in these solutions was then determined by using a flame photometer and from this a calibration curve was prepared. $3 \% \mathrm{H}_{2} \mathrm{O}$ solution of tomato sample was prepared and the potassium in it determined using the same flame photometer. The amount of potassium in this was then estimated by reading it off the calibration curve.

\subsubsection{Ash content}

The ash was determined following the method of AOAC (1984). Samples were weighed $(5 \mathrm{~g})$ accurately in a previously cleaned and dried- weighed crucible. At first the crucible containing sample was placed in an oven $\left(100-105^{\circ} \mathrm{C}\right)$ for $4 \mathrm{hrs}$ to remove moisture. The moisture free sample was completely charred in a heating mantle followed by ashing in a muffle furnace at $600^{\circ} \mathrm{C}$ for $3 \mathrm{hrs}$. Then it was removed from furnace and cooled in desiccators and weighed. To ensure complete ashing, the crucible was again heated in a muffle furnace for one hour. Then this was removed from the furnace, cooled in a desiccator and weighed again.

\subsection{Total soluble solid}

\section{Results and Discussion}

The result of the effect of storage temperatures on the total soluble solid (TSS) is presented in fig. 2. It was observed that differences existed between the post harvests temperature treatments at all stages of observation $(1,2,3,4,5,6,7$ and 8 weeks). The total soluble solid of the tomato samples was found to decrease with storage time with the rate of decrease of samples outside greater than those in the fridge, while that of the powder samples was minimal. The reason for this could be attributed to the higher storage temperature of the ones outside which could have led to increase in rate of spoilage, the bacteria (Bacillus thermoacidurans) probably being able to flourish better at this temperature. Another cause for the decrease could also be that the solids are probably broken down during storage time. These observations agree with the findings of Bachman and Earles (2000), who observed that fruits storage at extremely low temperature preserves quality better at increased storage periods. They also confirmed that temperature is the single most important factor in maintaining quality after harvest. In a similar development, Wilson et al. (1995) in their report on post harvest handling and cooling of fresh fruits, vegetables and flowers for small farms, asserted that deterioration of fresh commodities can result from physiological breakdown due to natural ripening processes, water loss, temperature, injury, physical damage or invasion by microorganisms and that all of these factors can interact and all are influenced by temperature.

\subsection{Insoluble solid}

Over the period of 8 weeks in which the study was carried out, the insoluble solid of the samples decreased. The rate of decrease was found to be greater for the first 4 weeks after which it was reduced (Fig. 3). However, for the powder samples, the change in the insoluble solid content was quite insignificant over the period of storage as compared to other samples. The trend of change observed could probably be due to the rate of spoilage which softens the solids of the samples hence, the decrease. 


\section{$3.3 \mathrm{pH}$ and Total acidity}

The $\mathrm{pH}$ of the tomato samples decreased with storage time up to the fourth week after which it started increasing, while the acidity of the samples increased for the first 4 weeks after which it began to decrease (Fig. 4). This observation was closely related to the observation made by Zackel and Schillinger (1979) who reported a decrease in the content of acids even up to $32 \%$ of the initial value. The $\mathrm{pH}$ of the powder samples increased after the $3^{\text {rd }}$ week. This observation agrees with the work of Garango et al. (1992) who attributed that the decrease in ascorbic acid content was correlated to the lowering of the $\mathrm{pH}$. The later increase in $\mathrm{pH}$ and decrease in acidity is probably due to the effect of organisms responsible for the spoilage, some of which can release basic substances into the samples. Lisiewska and Kmiecik (1999) observed an increase in total acid content of frozen tomatoes.

\subsection{Salt content}

A decrease in the salt content of the tomato samples was noticed (Fig. 5), the exception being the powder samples for which increase can be noticed. A marked difference can be observed in the salt content of the 3 sets of samples, that of powder ones being the highest. This is due to the fact that the powder samples have more concentration of tomato content and solid, the water content having been removed in the process of drying. The effect of use of salt as a preservative can be seen in the marked difference between the salt content of samples FsO, FsF, DsO, DsF, PsO, PsF and the corresponding counterparts, that of these samples being higher.

\subsection{Sugar content}

Within the 8 weeks in which the study was carried out on the tomato samples, significant differences in sugar content were observed (Fig. 6). Similar observation has been reported by Okanlawon (2002). The decrease in the sugar content of the fresh samples is more significant than that of the others. A difference can also be observed in the range of decrease of the sugar content of the samples outside and those in the fridge. This can be attributed to the storage temperature difference which affects rate of spoilage. In contrast, Raffo $e t$ al. (2002) reported an increase in the sugar content of tomato due to metabolic break down of organic acid into carbon dioxide and polysaccharides into water soluble sugar as glucose, fructose and sucrose as ripening progress.

\subsection{Ascorbic Acid}

Loss in ascorbic acid content of the tomato samples with storage time can be observed from Fig. 7, with the rate of decrease of the fresh samples being less than that of the other samples. In the first week, the ascorbic acid in the dehydrated samples was found to be less than that of the fresh samples while none was detected in the powder sample. The higher temperature at which these samples were prepared is probably responsible for this, the loss of ascorbic acid having been reported to be corresponding to temperature (Garango et al, 1992; Hobson and Davies, 1971). The results obtained in this study are in a good agreement with those reported by Gupta and Nath (1984) and Gallali et al. (2000). Lavelli et al. (1999) reported that the content of ascorbic acid decreased from $3300 \mathrm{mg} / \mathrm{kg}$ of dry matter in fresh dried tomatoes at temperature $80^{\circ} \mathrm{C}$. According to Toor and Savage (2006) the drying tomatoes at $42^{\circ} \mathrm{C}$ for 18 hours led to ascorbic acid losses between $17-27 \%$ depending on the tomato varieties.

\subsection{Potassium content}

An increase in the potassium content of the samples was noticed (Fig. 8); this increase ranged from 9.75 to $12.82,9.25$ to 13.40 and 10.00 to 13.23 for the fresh, dehydrated and powder samples respectively. The effect of the type of preservation on the tomato samples was found to be quite insignificant.

\subsection{Ash content}

The fresh and dehydrated tomato samples showed a marked decrease in ash content over the period of storage, but that of the powder ones were minimal. This could probably due to the decrease of the salt content of the samples (Fig. 9). The high ash content of the powder samples is followed by the dehydrated ones and then the fresh. This is because of the increased tomato content and solid of the powder samples that are due to the removal of water content during their preparation which involved drying to various degrees. The results obtained are in close conformity to those reported by Ereifej et al. (1997). 


\section{Conclusion}

The total solid, insoluble solid, $\mathrm{pH}$, sugar, salt, ascorbic acid and ash content of the 16 samples were found to decrease with storage time, with that of the powder samples being less significant than the others, while the acidity of the samples showed an increase. Of the three sets of the tomato samples, the powdered ones were found to last longer and its chemical constituents showed minimal change over the period of study. This is thus recommended as the best of the methods used for preservation of the tomatoes, despite the total loss of ascorbic acid. A possible suggestion to meet this defect is to add a calculated quantity of ascorbic acid after preparation.

\section{References}

[1]. Akbudak, B. \& Akbudak, N. (2007). Effect of hot water treatment and modified atmosphere packaging on the quality and cold storage life of cherry tomatoes. Journal of Food Science and Technology, 44: 216-219.

[2]. AOAC, Association of Analytical Chemists. (1984). Moisture in dried fruits. In: Williams S, editor. Official methods of analysis of the Association of Official Analytical Chemists. Arlington, Va.: AOAC. pp, 415.

[3]. AOAC. (1995). Official Methods of Analysis of the Association of Official Analytical Chemists, Edn. 14th Washington, D.C. pp. 125-139.

[4]. Bachman, J. \& Earles, R. (2000). Post harvest handling of fruits and vegetable. ATTRA Horticultural Technical note 19.

[5]. Bauerfeind, J. D., \& Pinkert, D. M. (1970). Food processing with added ascorbic acid. Advanced Food Research, 18: 219.

[6]. Brecht, P. E., Kengl, B. \& Munyer, H. M. (1976). Effect of fruit portion, stage of ripeness and growth habit on chemical composition of fresh tomatoes. Journal of Food Science, 41: 945.

[7]. Ereifej, K. I., Shibli, R. A., Ajlouni, M. M. \& Hussain, A. (1997). Physico-chemical characteristics and processing quality of newly introduced seven tomato cultivars into Jordan in comparison with local variety. Journal Food Science and Technology, 34: 171-174.

[8]. Fatunla, T., \& Ogunsua, A. O. (1972). Planning a breeding programme for processing type tomatoes. Nigerian Journal of Science, 6: 163 .

[9]. Foda, Y. H., \& McCollum, J. P. (1970). Viscosity as affected by various tomato constituents of tomato juice. Journal of Food Science, 35, 333.

[10]. Francois, M. (1995). Transformer les fruits tropicaux. Collection le Point sur les Technologies GRET - Ministere de la Cooperation Francaise - CTA - ACCT, Paris, 226.

[11]. Gallali, M. Y., Abujnab, Y. S. \& Bannari, D. F. (2000). "Preservation of fruits and vegetables using solar drier: a comparative study of natural and solar drying, III; chemical analysis and sensory evaluation data of the dried samples," Renewable Energy, 19: 203212.

[12]. Garangyo, T., Thiombiano, T., Werem, A., Drawara, B., \& Sawadogo, L. (1992). Etude de l'impact du sechage solaire direct sur la teneur en vit $\mathrm{c}$ de la tomato. Science Technology, 20: 53-61.

[13]. Geeson, J. D., Maddison, K., \& Broune K. M. (1981). Modified atmosphere packaging of tomatoes. in packaging of horticulture, produce. AAB/NCAE Residential Meeting. London, 8-15.

[14]. Geeson, J.D., Broune, K.M., Maddison, K., Shepherd, J., \& Guaraldi, F. (1985). Modified Atmosphere Packaging to Extend the Shelf life of Tomatoes. Journal of Food Technology, 20: 339-349.

[15]. Goose, P. G. \& Binsted, R. (1973). Tomato paste and other tomato products. Food Trade Press Ltd., 180.

[16]. Gupta, R.G. \& Nath, N. (1984). Drying of tomatoes. Journal of Food Science and Technology, India, 21: 372-376.

[17]. Hong, M.N., Lee, B. C., Mendonca, S, Grossmann, M. V. E., \& Verhe, R. (1999). Effect of infiltrated calcium on ripening of tomato fruits. LWT Journal of Food Science 33: 2-8.

[18]. Lavelli, C. W., Hippeli, S., Peri, C. \& Elstner, E. F. (1999). Evaluation of radical scavenging activity of fresh and air dried tomatoes by three model reactions. Journal of Agriculture and Food Chemistry, 47: 3826-3831.

[19]. Lisiewska, Z. \& Kmiecik, W. (1999). Effects of storage period and temperature on the chemical composition and organoleptic quality of frozen tomato cubes. Journal of Food Chemistry, 70: 167-173

[20]. Maul, F., Sargent, S. A., Sims, C. A., Baldwin, E. A., Balaban, M.O., (2000). Tomato flavuor and aroma quality as affected by storage temperature. Journal of Food Science 65: 1228-1237.

[21]. Mozumder, N. H. M. R., Rahman, M. A., Kamal, M.S., Mustafa, A. K. M. \& Rahman, M.S. (2012). Effects of pre-drying treatment on quality of cabinet dried tomato powder. Journal of Environmental and Natural Resources, 5: 253-265

[22]. Mustafa, A. \& Mughrabi, A. L. (1994). Effect of packaging methods on the quality characteristics of tomato fruits produced in hydroponics. Journal of King Saud University. 6: 71-76.

[23]. Okanlawon, S. O., Ibrahim, M. H. \& Oyebani, A. O. (2002). Effect of pre drying treatment on the storage of dried tomato. Tropical Science, 42: 40-41.

[24]. Opiyo, M. A., \& Ying, T. J. (2005). The effects of 1-methylcyclopropen treatment on the shelf life and quality of cherry tomato (Lycopersicon esculentum var. cerasiforme) fruit. International Journal of Food Science and Technology, 40: 665-673.

[25]. Pearson, D. (1976). Chemical Analysis of Food $7^{\text {th }}$ Ed., Churchill Livingston.

[26]. Pearson, D. (1982). Chemical Analysis of Food $8^{\text {th }}$ Ed., Churchill Livingstone, 150-168

[27]. Peterson, J. (1974). Tomatoes Encyclopedia of Food Technology and Food Science Series. Avi Publishing Co. Inc, Westport, Connecticut, 2: 899

[28]. Raffo, A., Leonardi, C., Fogliano, V., Ambrosino, P. \& Salucci, M. (2002). Nutritional value of cherry tomatoes (Lycopersicon esculentum Cv. Naomi F1) harvested at different ripening stages. Journal of Agriculture Food Chemistry, 50: 6550-6556.

[29]. Risse, L. A., Miller W. R., \& Ben-Yhoshua, (1985). Weight loss, firmness, colour and decay development of individual film wrapped tomatoes. Tropical Science. 25: 117-121.

[30]. Roberts, P. K., Sargent, S. A. \& Fox, A. J. (2002). Effect of storage temperature on ripening and postharvest quality of grape and mini-pear tomatoes. Proc Fla State Horticulturel Society, 115: 80-84.

[31]. Sakunkhe, D. K. (1974). Storage, Processing and Nutritional Quality of Fruit and Vegetable CRC Press, CRC Press Inc. $18901,44$.

[32]. Simonne, A. H., Behe, B. K., \&Marshall, M. M. (2006). Consumers prefer low-priced and high-lycopene-content fresh-market tomatoes. Horticultural Technology, 16: 674-681.

[33]. Stanly, D. W., Bourne M. C., Stone, A. P., \& Wismer, W. V. (1995). Low temperature blanching effects on chemistry, firmness and structure of canned green beans and carrots. Journal of Food Science, 60: 327-333.

[34]. Thybo, A. K., Christiansen, J., Kaack, K., \& Petersen, M. A. (2006). Effect of cultivars, wound healing and storage on sensory quality and chemical components in pre-peeled potatoes. LWT Journal of Food Science and Technology, 39: 166-176.

[35]. Toor, R. K. \& Savage, G. P. 2006. "Effect of semidrying on the antioxidant components of tomatoes". Food Chemistry, 94: 90-97. 
[36]. Tyssandier, V., Feillet-Coudray, C., Caris-Veyrat, C., Guilland, J., Coudray, C., Bureau, S., Reich, M., Amiot-Carlin, M., Bouteloup-Demange, C., Boirie, Y., \& Borel, P. (2004). Effect of tomato product consumption on the plasma status of antioxidant microconstituents and on the plasma total antioxidant capacity in healthy subjects. Journal of American College Nutrition, 23: 148156

[37]. Weisburger, J. H. (2002). Lycopene and tomato products in health promotion. Experimental Biological Medicine, 227: $924-927$.

[38]. Weister, H. H. (1971). Practical Food Microbiology and Technology. Avi Publishing Co. Westport, Conn, $2^{\text {nd }}$ Edition.

[39]. Wiberg, L. A. S. (1977). Avd. Koksvax fodling, Inst. Trad gardsve Tensk. Land skapsplanering. Lantbrukshoegsh Medd. Ser. A, 267: 24 .

[40]. Wilson, L. G., Boyette, M. D. \& Estes, E. A. (1995). Post harvest handling and cooling of fruits, vegetables and flowers for small farms, part 1: quality maintenance. Wilson, L. G., Boyette, M. D. and Estes, E. A., (Eds.), N. C. Coop. Extension Service Horticultural Information, Leaf No. 800, 4.

[41]. Yang, C. C., \& Chinnan, M. S. (1988). Modeling the effect of oxygen and carbon (IV) oxide on respiration and quality of stored tomatoes. American Society of Agricultural Engineers, 31: 920-925.

Figure 1: Effect Of Length Of Storage On Total Solid Content Of Tomato

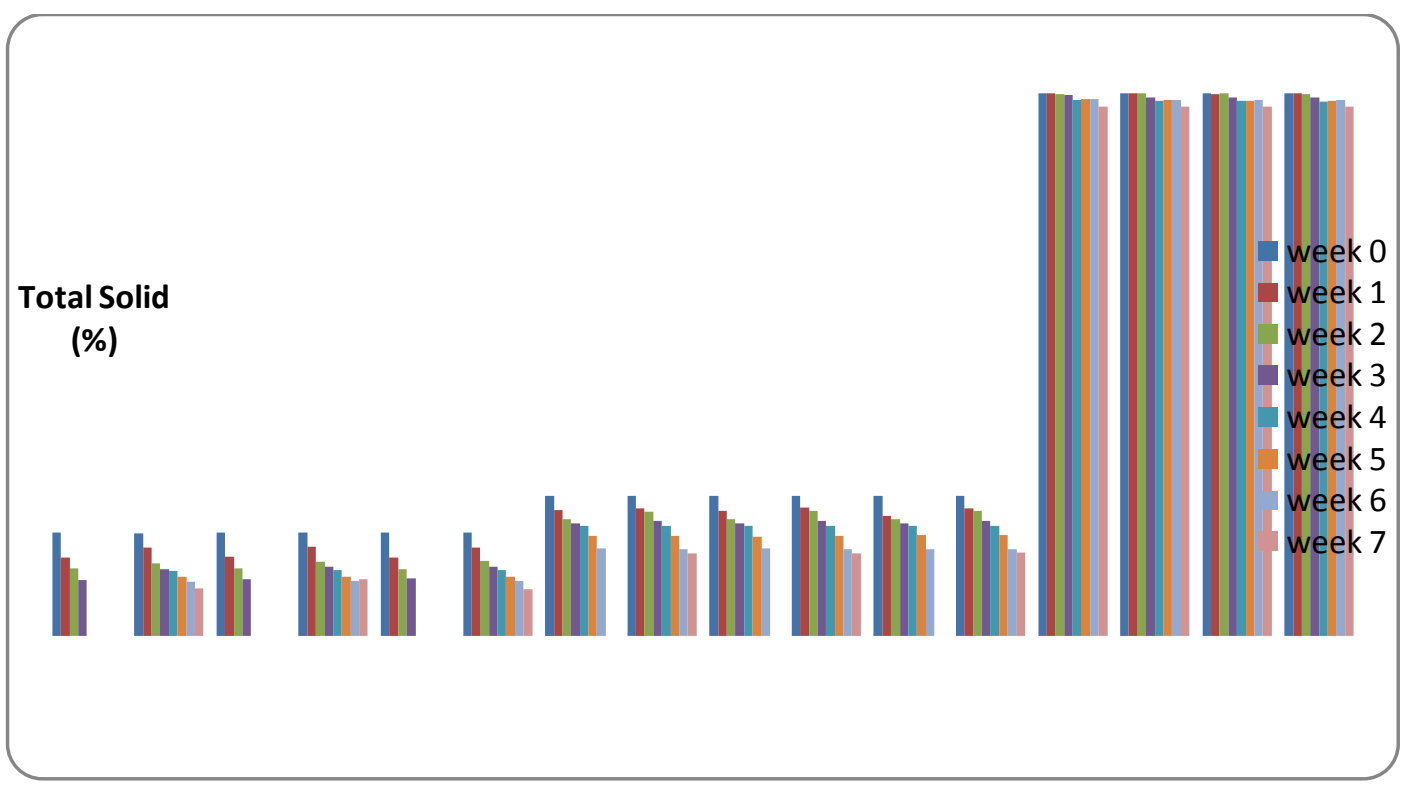

FIGURE 2: EFFECT OF LENGTH OF STORAGE ON THE INSOLUBLE SOLID CONTENT OF TOMATO

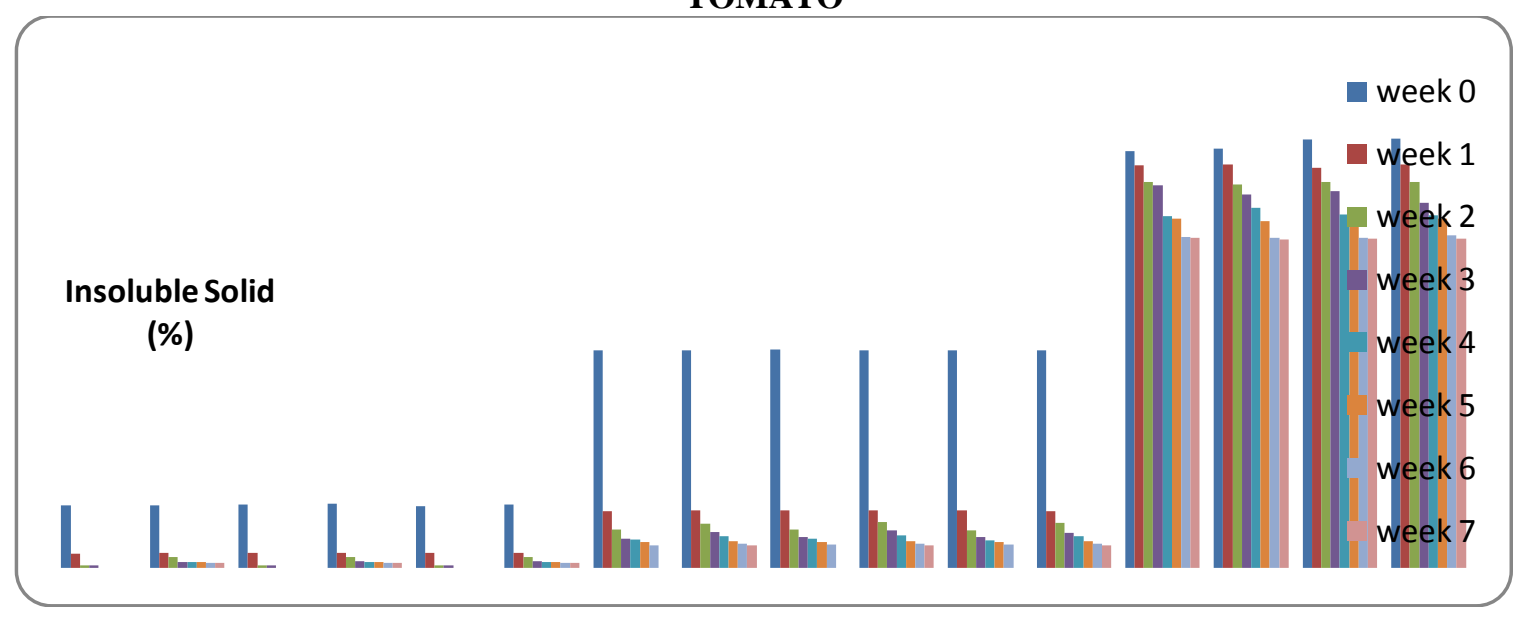


FIGURE 3: EFFECT OF LENGTH OF STORAGE ON THE pH OF TOMATO

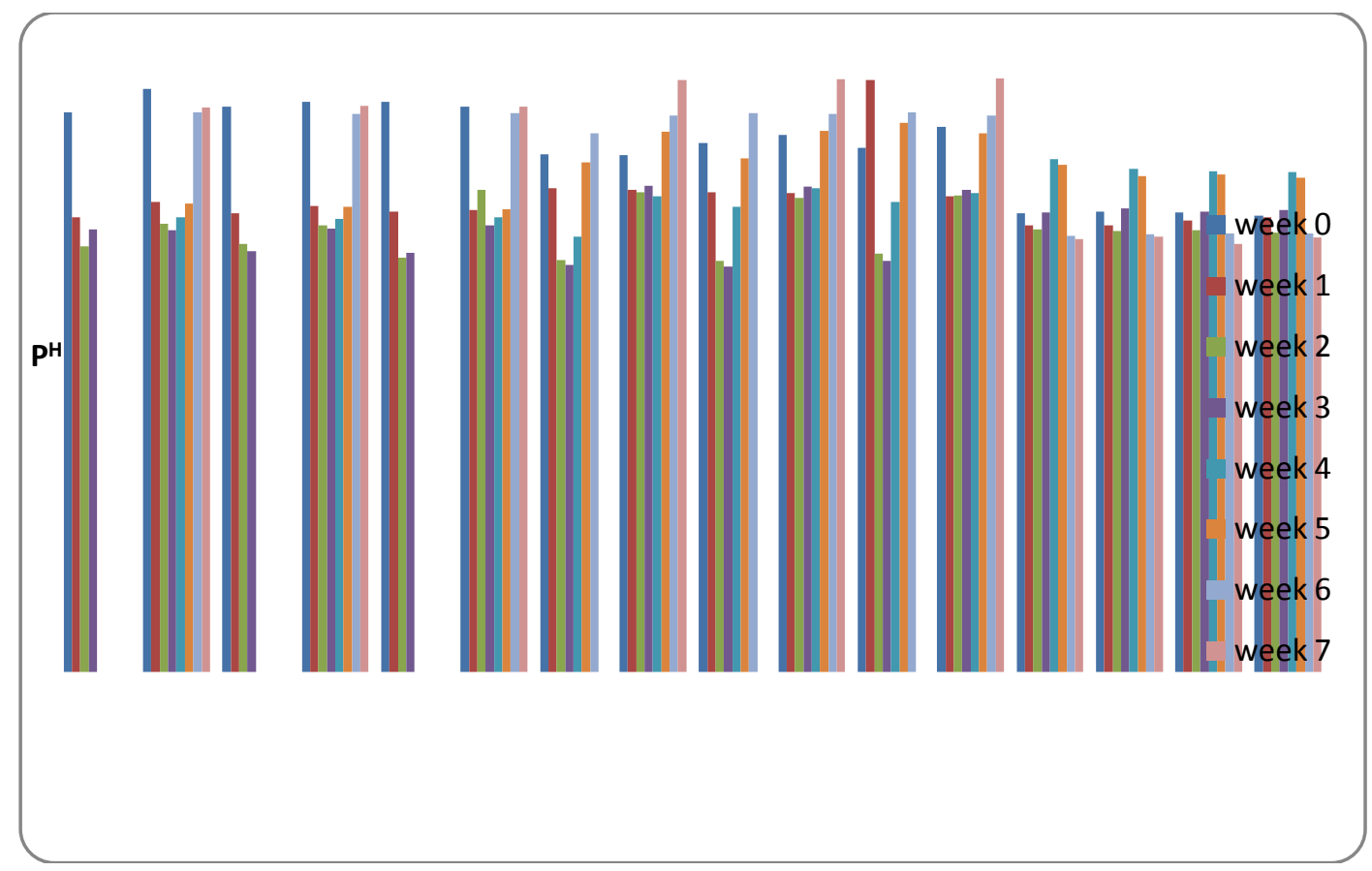

FIGURE 4: EFFECT OF STORAGE LENGTH ON THE SALT CONTENT OF TOMATO

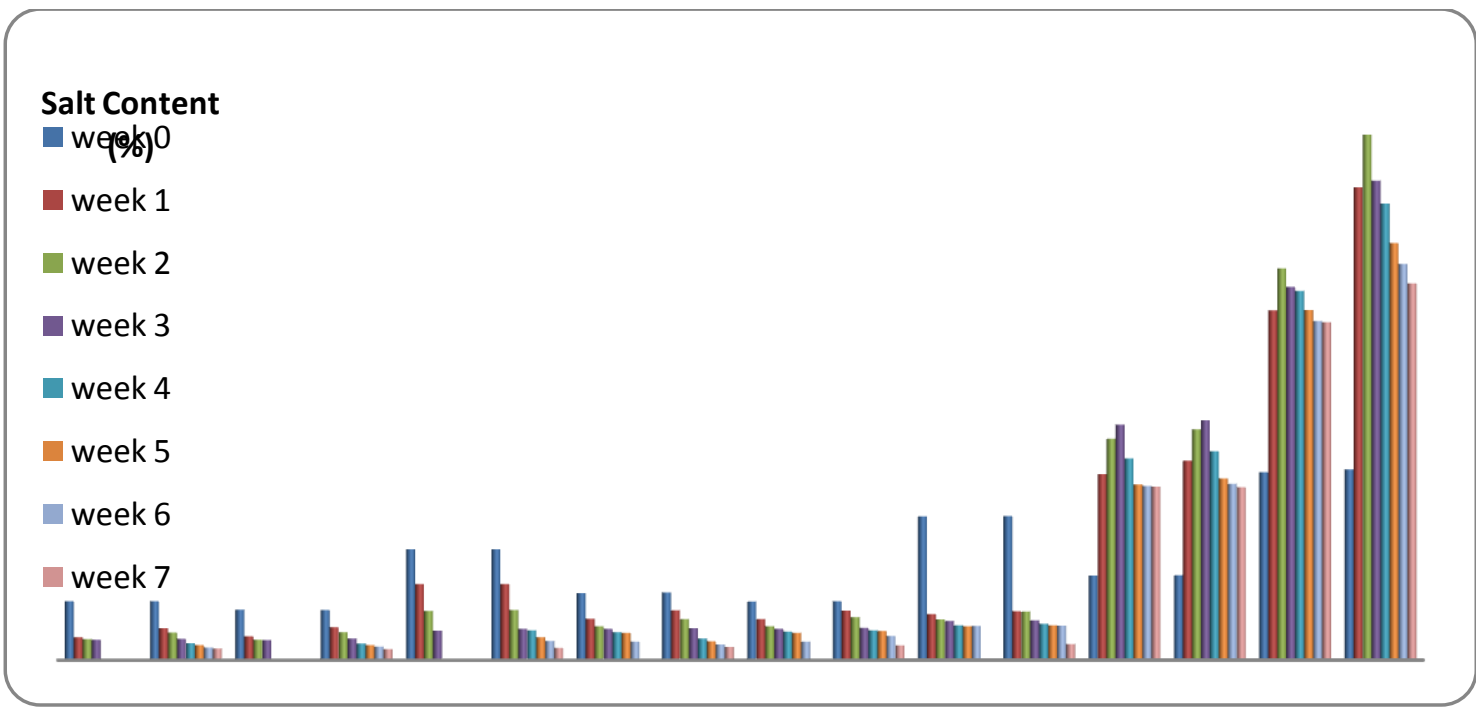


FIGURE 5: EFFECT OF LENGTH OF STORAGE ON THE SUGAR CONTENT OF TOMATO

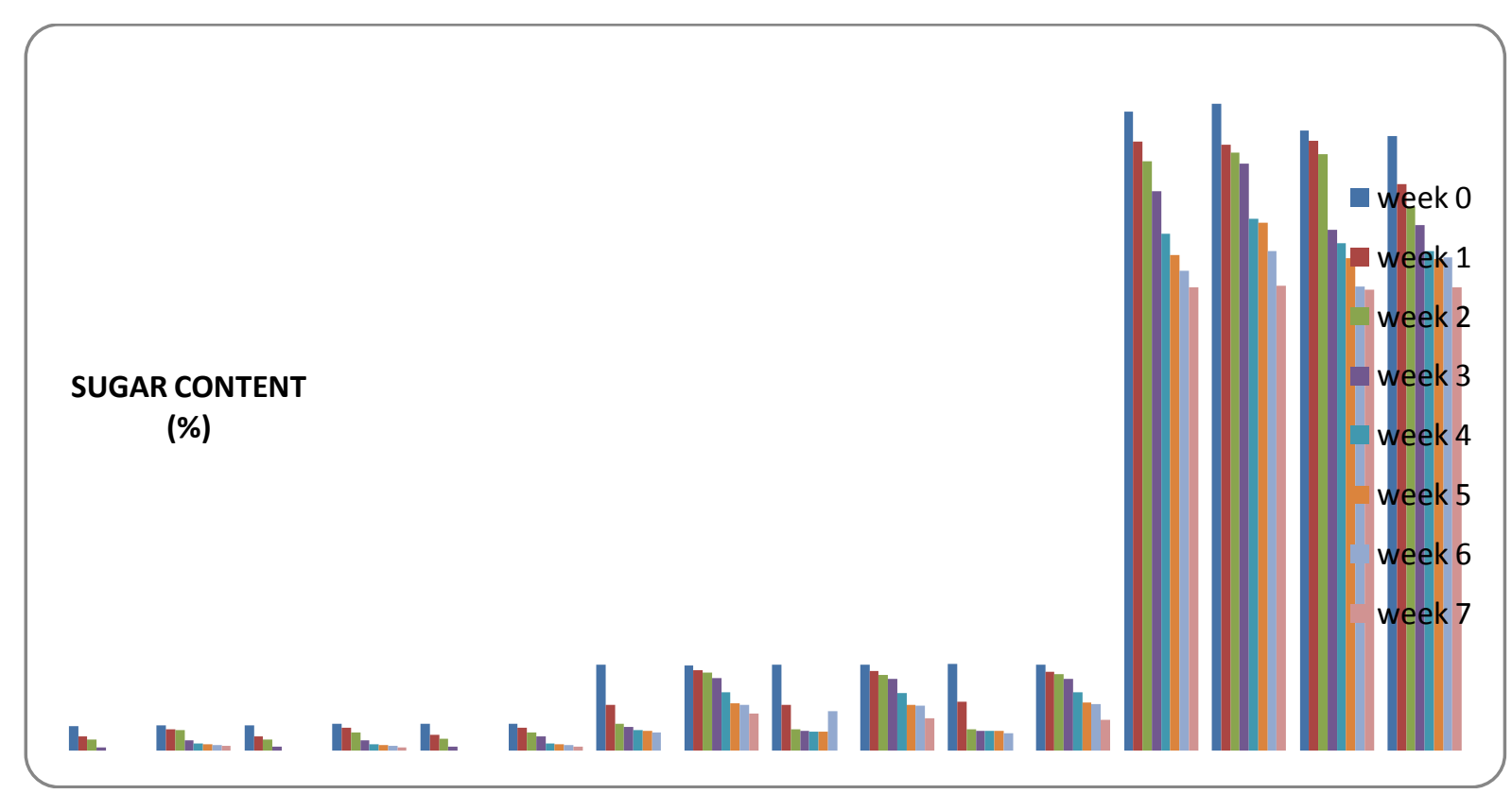


FIGURE 6: EFFECT OF LENGTH OF STORAGE ON THE ASCORBIC ACID CONTENT OF TOMARO

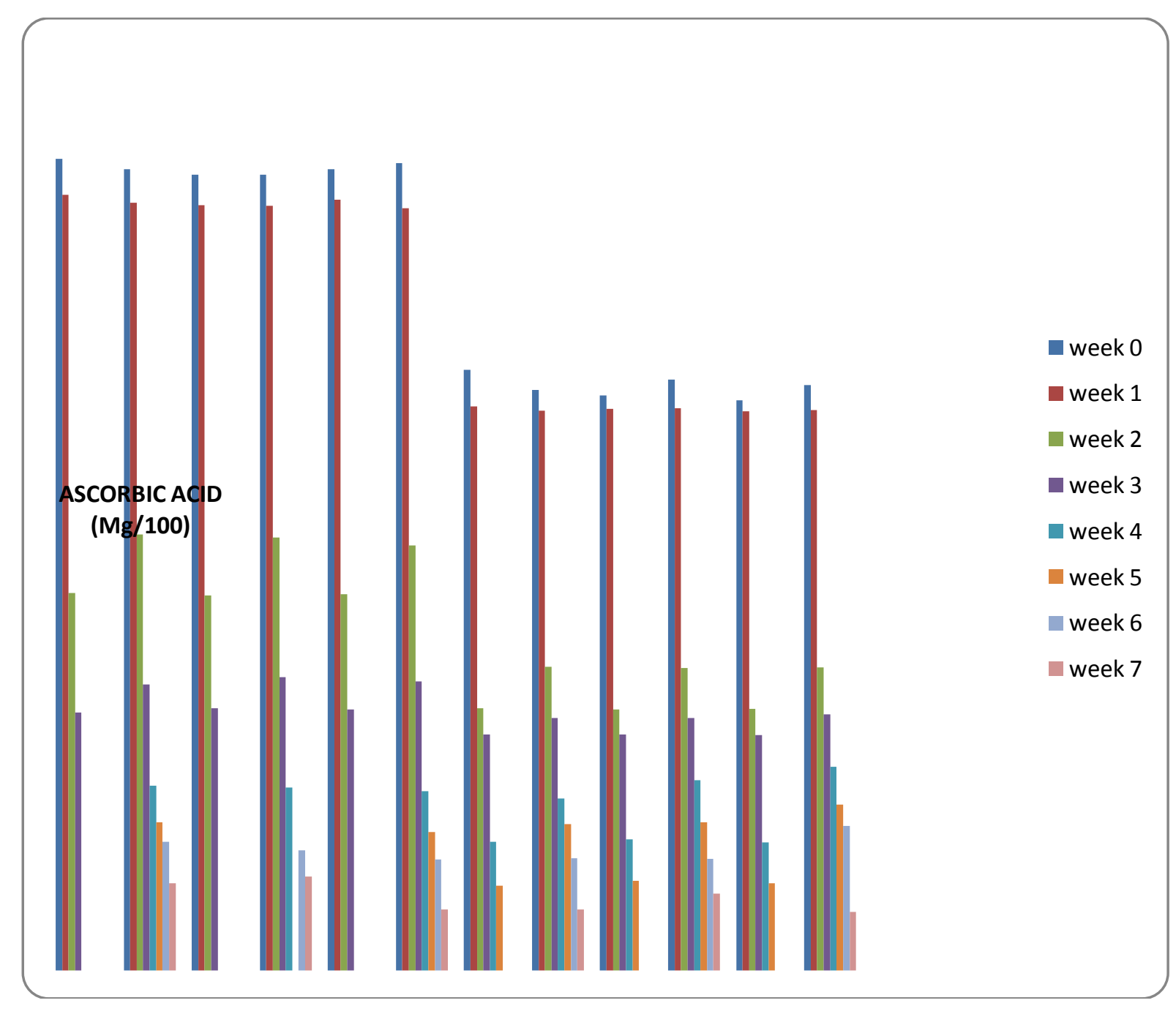


FIGURE 7: EFFECT OF LENGTH OF STORAGE ON THE POTASSSIUM CONTENT OF TOMATO

Potassium Content (mg/l)

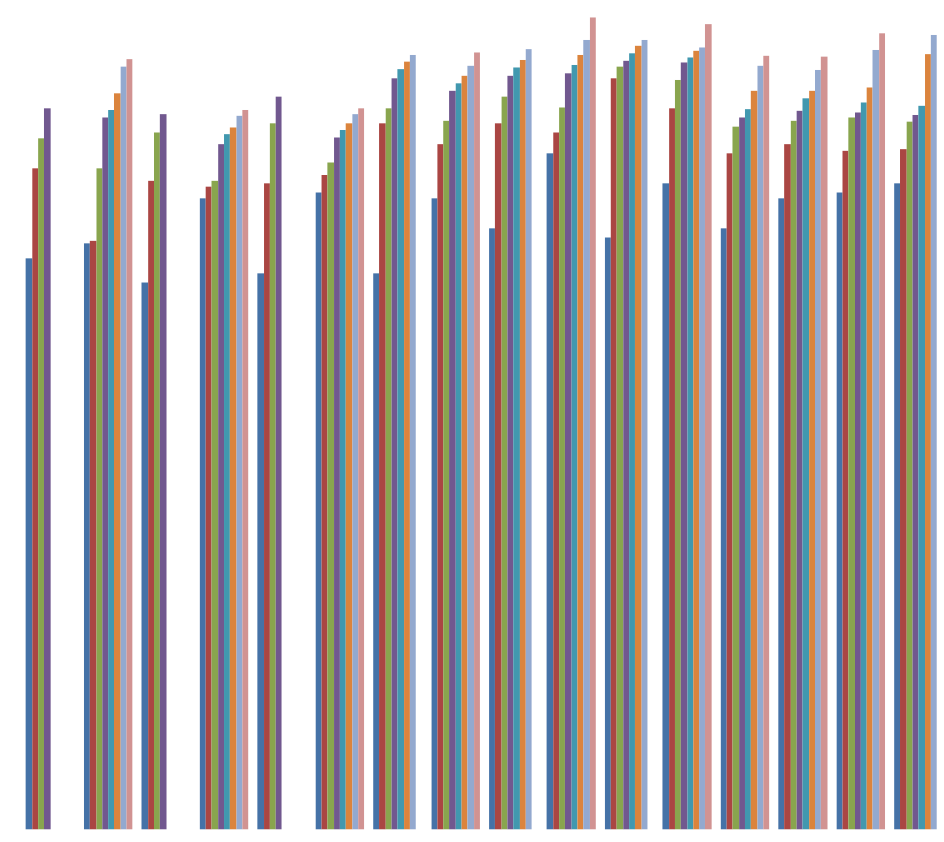

week 0

week 1

week 2

week 3

week 4

week 5

week 6

week 7 
FIGURE 8: EFFECT OF STORAGE ON THE ASH CONTENT OF TOMATO

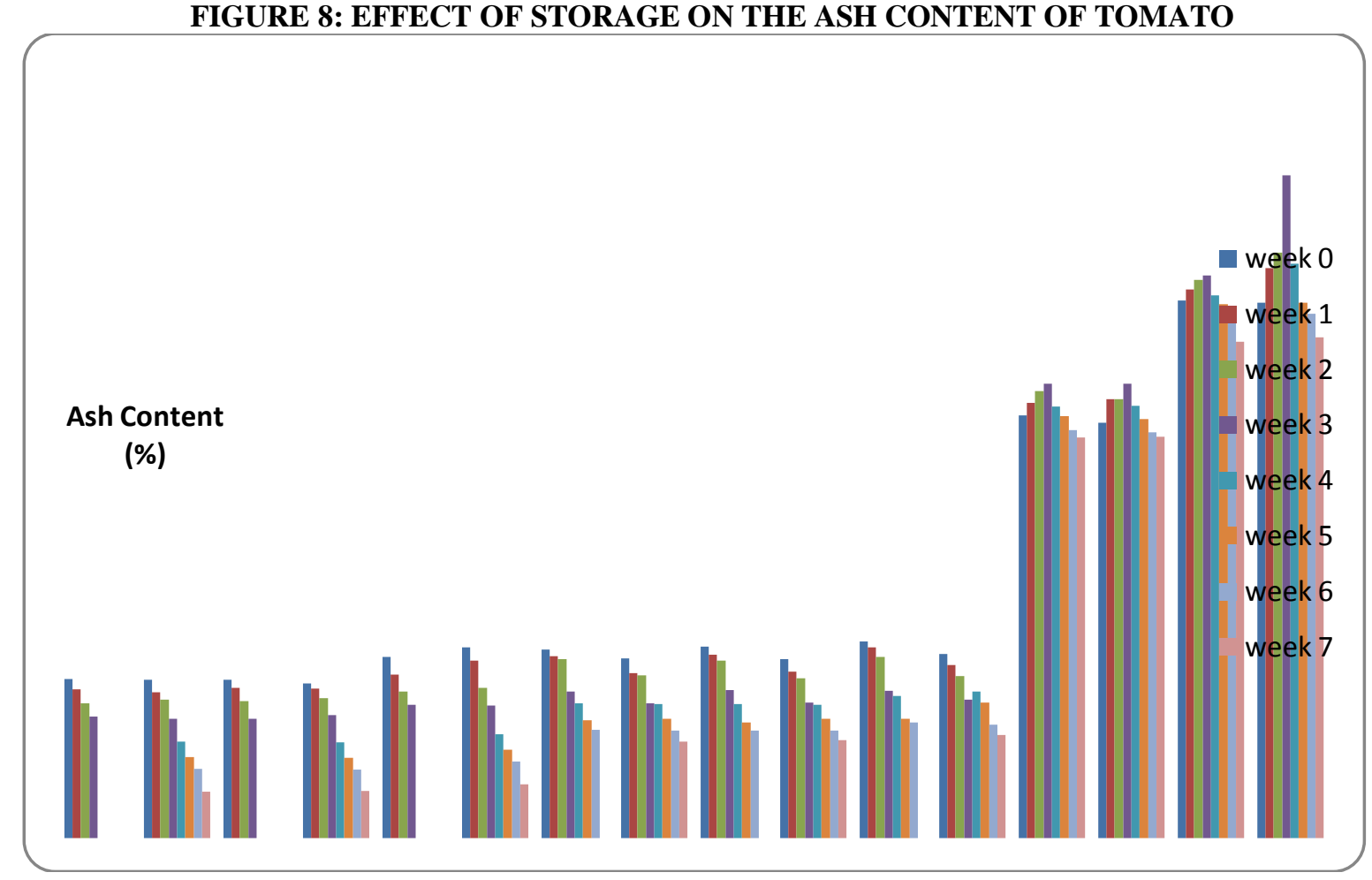

